\title{
China's Aid and Smart Power in Africa: A Different Partnership and Cooperation Model
}

\author{
Viviane Bayala \\ Norbert Zongo University \\ Avenue Maurice Yameogo B.P. 376, Koudougou, Burkina Faso \\ E-mail: edikir9@yahoo.com
}

\begin{abstract}
Kemo Badiane (Corresponding author)
Nanfang College of Sun Yat-Sen University
\end{abstract}

Wenquan town, Conghua District, Guangdong Province, Guangzhou, 510970, China

E-mail: didibadiane@gmail.com

Received: August 24, 2020 Accepted: October 30, 2020 Published: December 4, 2020

doi: 10.5296/jsss.v8i1.17576 URL: https://doi.org/10.5296/jsss.v8i1.17576

\begin{abstract}
Essentially based on the analysis of documentary and oral sources collected in libraries and from networks, this paper reexamines the Chinese approach in the field of development aid. It is based on the premise that the Chinese aid policy in Africa combines realism and idealism to reach its foreign policy goals in Africa, and this singularity is firmly rooted in old-fashioned principles stemming from the Chinese strategic culture. To show this assertion is relevant, the article includes three sections. The first section analyzes the cultural principles which determine the Chinese foreign policy as a whole; whereas the last two sections explain their relevance on the realist and idealist dimensions of China's aid policy in Africa. Finally, we discuss the implications of China's approach in the field of development aid.
\end{abstract}

Keywords: Foreign aid, Smart power, Singularity, Culture, China-Africa

\section{Introduction}

Smart power is "the ability to combine hard and soft power into a successful strategy" (Nye, 2007). Much more explicitly, it is "the full range of tools at our disposal - diplomatic, economic, military, political, legal, and cultural — picking the right tool, or combination of 
tools, for each situation" (Hertzberg, 2009). The concept was first used by Suzanne Nossel in an article published in 2004 in Foreign Affairs, and further spread by Joseph Nye (2004), the author of Soft Power. According to Nye, hard power is the capacity of a country to reach its goals by using military might and economic influence. This tradition was key to the old world of military violence that waned at the end of WWII. During the Cold War, the world enters into a time of dissuasion that commands persuasion and negotiation which mark the emergence of soft power in post-Cold War era. It puts forwards new forms of cooperation that include culture, economy, law, communication in order to win the hearts and minds of the people. As the world is growing more and more complex under the influence of globalization and the rise of non-traditional threats (e.g., terrorism, environment, etc.), the concept of smart power suggests an intelligent use of hard and soft powers in accordance with countries designed policy goals. In this paper, we argue that China uses its aid as a smart power tool to instigate a different partnership and cooperation model in Africa. For a sound understanding of this assertion, there is a need to review the concept of foreign aid and the state of China's aid in Africa.

Foreign aid or "cooperation for development" refers to a sovereign country's decision (or an international institution's) to transfer financial and technical resources to another country or region through the world (Zamora, 1997; Callan, 2000). This concept initiated by the USA was institutionalized in the late 1940s after the success of the Marshall Plan (April 1948-December 1951), and the allied countries' agreement to transfer important sums of money and their technological know-how to Asian and African countries which had just acquired their independence (World Bank, 1998). Therefore, foreign aid is, at the beginning, a Western ideological construction that is part and parcel of donor and recipient countries' foreign policies (Thérien, 2008).

At the beginning of this $21^{\text {st }}$ century, The People's Republic of China (PRC) has become a key player in the field of aid for development. The amount of its foreign aid to developing countries rose from $\$ 20$ billion during the conference of the Forum on China-Africa Cooperation (FOCAC) in 2012 to a promise of $\$ 60$ billion in 2018 (La Croix, 2018). This Chinese commitment in Africa testifies to the idea of a paradigm change in the foreign aid policy in this early millennium (Thaler, 2012). The first official report on Chinese foreign aid published in 2011 confirms this remark. In it, it is said China has procured financial assistance all over the world, and till 2009, the country paid out Yuan 256.29 billion. Africa was given 47.5\%, followed by Asia (33\%), then Latin America (13\%) and last Oceania (4\%) (Huang \& Ren, 2012). The second official report on the Chinese foreign aid published in July 2014 shows that from 2010 to 2012, Africa remained the main destination of China's aid (Xinhua, 2015). It received up to $51.8 \%$ of the entire aid estimated to Yuan 89.39 billion (about \$ 14.41 billion) compared to $30.5 \%$ for Asia and $8.4 \%$ for Latin America and the Caribbean (Office of the State Council, July 2014). The Center for Democratic Governance (CDG) corroborates these data. It shows that emerging countries' aid for development varies from $\$ 11$ to 42 billion every year and China is the main emerging donor, which presently procures, much more financial aid than the World Bank (Thaler, 2012).

The Chinese entire aid significantly evolved from 2002 to 2009, going from \$ 603 million in 2002 to \$ 1,033 million (2006), and \$ 1,945 million (2009) (Huang \& Ren, 2012). The 2014 
official report completes these data with a cumulative amount of $\$ 14.9$ billion from 2010 to 2012 (The State Council, 2014). It is obvious these figures are much more impressive than those of the Cold War period, even though the latter remains important when referring to the context according to Li (2011). Best, nowadays, China is also the country possessing the most important world exchange reserves estimated to 3.103 .698 billion far before the remaining four superpowers of the United Nations Security Council (The People's Bank of China, 2019). Better than any other country, China is at the best position to invest, lend, or offer donations to countries in real needy situations. Therefore, for the first time, in the history of foreign aid, an emerging oriental power possesses political, military and particularly economic assets to establish itself on the international scene as a key aid-giver to African countries in addition to traditional Western givers. This new order requires the understanding of philosophical foundations which underlies the Chinese aid policy on the continent. Therefore, this article defends the idea that China's approach is, particularly, distinguished by its taking roots in the ancient principles of the Chinese strategic culture.

\section{The Chinese Approach: A Cultural Singularity}

China or People's Republic of China in full is a former Asian state which, officially, became a communist state in 1949 under Mao Zedong's leadership (Bergère, 1987). Like contemporary states, it conceived a foreign policy, which determines the key objectives guiding the country's general activities in the framework of its relations with other countries all over the world (Ethier, 2010). Aid is part and parcel of China's foreign policy, so it difficultly escapes from the influence of the Chinese strategic culture. That is to say the originality of the Chinese approach to development aid depends on the fact that its formulation is inspired by ways the Chinese display in their attempts to solve or think about some national and international security issues.

"Chinese Strategic Culture" is usually discussed in relation to Chinese foreign policy. For example, Lin (2008) highlights the influence of Chinese strategic culture in Chinese recent foreign policy evolvement. First, the persistence of the three (3) principles: "One country, two systems", "peaceful unification", and the "non-renunciation of the use of force against Taiwan". Second, the country's attachment to orthodox order and the use of Chinese traditional dialectics of opposing wills: yin-yang in handling the Cross-Strait policy. Hunt (1996) uses a historical perspective to describe Chinese communist foreign policy stressing the importance of history to understand Chinese foreign policy. Shih (1993) addresses the influence of "morality" forms by legacies of humiliations impacting China's foreign policy making. Fairbank (1968) explains that Chinese foreign policy is a mixture of Sun and Confucius and realism. Iain (1995), similarly, asserts that every country has its own strategic culture and strategic culture approach does not reject rationality. In developing the ideas sustaining the argument abovementioned, we are particularly stressing Chinese dialectics of opposing wills: yin-yang which is different from Western perception. As pointed out here, "Western dialectical thinking is fundamentally consistent with the laws of formal logic, and aggressive in the sense that contradiction requires synthesis rather than mere acceptance. The key difference is that Chinese dialecticism does not regard contradiction as illogical and tends to accept the harmonious unity of opposites" (Nisbett, 2003).

In Chinese tradition, the Yin-yang, being the sources of everything, is the driving force of the 
world in all its aspects. The Yin is considered passive, docile, and protecting, whereas the Yang is active, prevailing, and creative. These concepts were abundantly spread by Taoism and Confucianism among many other Chinese philosophical schools (Huang \& Huang, 1987:7). Although it is difficult to find for it a conceptual definition, despite interpretation, application and appropriateness differences of the concept, three basic themes are mentioned in the Chinese philosophy: (1) Yin-yang as a coherent manifestation, of the nature and mind, is present in any existence, (2) Yin-yang as an interaction between cosmic and human reality, and (3) Yin-yang as a harmonization process which ensures a dynamic and constant balance between things (Wang 1983). Thus, the Chinese terminologies Yin (陰) and Yang (陽), though representing different realities, are integrated and complementary. They refer to "coherence", "interaction", and "harmony" in the Chinese cosmogony (JDBN, 2016). In this article, the premise is that similarly to the Yin-yang alternation, China's foreign policy is devised to concomitantly satisfy its national interests while caring about those of its international partners. And this is because without the satisfaction of national interests, it is difficult to be powerful on the international scene, and without a significant international influence, the satisfaction of national interests is not guaranteed for a long period. All this process takes place in a specific Shi (world context).

The Shi expresses power configuration and change process in which a player acts or interacts. In the field of international relations, this generally refers to contemporary world's features and international power configuration (Guojigeju) (Zhu, 2010). In his book entitled, The Seven Treaties of Ancient China's Military Art, Sawyer highlights a philosophy of similar life. A conciliating dualism (yin-yang) teaches flexibility and combination of means to get adapted to internal and external circumstances (Shi) (Sawyer, 1993). The classics of the Chinese strategy such as the Art of War by Sun-Tzu (1971), I Shing (Zhu, 2010), Tao Te King by Lao-Tseu (2016) teach these principles. Ubiquity (shi) and the simultaneous use of conventional and non-conventional means (yin-yang) are very important to ensure victory in front of a more powerful enemy (Lai, 2004), with only a small and less expensive army. Better than any other strategist, Sun Tzu (1971) clarifies these key concepts of the Chinese strategic culture. His treatise, concise, is a world-famous one. Many contemporary authors quote him, and his principles are more and more promoted by the Chinese political community in its efforts to defend the idea of a "peaceful development of China" (Xinhuanet, 2018).

In the coming sections, the relevance of these principles is analyzed in accordance with the Chinese aid policy in Africa. It starts with the third section that discusses the elements of a realist policy but, which is, deeply rooted in the above-described Chinese strategic culture.

\section{The Chinese Aid to Africa: A Realist Policy but Flexible}

According to the authors from the realist school of international relations, aid is an instrument for China's foreign policy to defend its own self-interests (Gabas, \& Chaponnière, 2012) China's presence in Africa is first and foremost motivated by its own political and economic interests. Even if the Sino-African relation is always renewed, Africa remains the energetic/mineral raw material supplier, and China an ideal financial partner whose aid for development does not depend on any political condition (Lafarge, 2005). What's more, China is in fact nothing, but a former giver that reacts in an international environment undergoing 
massive changes and a major restructuring to promote the objectives of its home policy (Chaponnière, 2008). For others, the content and approach of the Chinese aid represent great challenges to traditional aid for development (Wang, 2012). China's aid is mainly interested in China's strategic objectives and economic needs, such as infrastructures to get access to oil and gas resources, but particularly markets that are necessary to China's economic development (Weston, Campbell, \& Koleski, 2011). If these authors describe a certain reality of China's aid policy in general, they are less specific about the cultural singularity of China's bilateral aid policy in African countries. This policy is realistic, but also flexible. It is realistic because it obeys conditions which match China's political and economic interests. The main difference with Western aid policy is at the level of constraint types required by China in return to its aid for development. If the conditions of Western aid are hard and inflexible, those of China are simple, flexible and open to recipients' countries. As it appears, China's approach seems to be inspired by Sun Tzu asserting that "supreme excellence consists in breaking the enemy's resistance without fighting” (Sun Tzu, 1971).

For instance, politically, the only constraint expressed by China's aid policy is the recipient countries' submission to the "One China" policy which has been required since the 1950s. All the African countries having diplomatic relations with People's Republic of China (PRC) are kindly requested to abide by this principle. This is an obligation clearly stated in the principles of the Chinese policy as follows:

Bearing in mind the five principles of peaceful coexistence, China respects the rights of receiving countries to freely choose their own way and model of development; in addition to, it believes that every country should explore a way to development in tune with its own reality. China has never used foreign aid as a means of interfering in receiving countries' internal affairs or seeking privileges for itself (Xinhua, 2014).

Thus, China has continuously refused to have formal political relations with African countries considering Taiwan as an independent country. But this requirement seems to be accepted by African countries which, one by one, broke their diplomatic ties with Taiwan and established new ones with PRC. The number of countries receiving China's aid went up from a small group of 14 partner countries (pro-communist) in the 1960s to 34 after PRC became a permanent member of the United Nations Security Council in the 1970s. During this first period, the most remarkable aid is a financial disbursement of F Switzerland 20 million for Egypt which was facing Western powers about its rights on the Suez Canal (1956), the building of sport and economic facilities in Guinea Conakry (1960), seven farming specialists to help Mali in its experience of sugar cane and tea plantations between 1961 and 1962. In 1965, a team was sent by the Chinese authorities to study the feasibility of Tanzania-Zambia railway. Moreover, about the late 1960s, China successively sent medical teams to Tanzania, Somalia, the Democratic Republic of Congo, Mali and Guinea, etc. (Li, 2006). Not only did these countries have any relation with Taiwan, but they were particularly pro-Communists.

In the 1980s, a period of economic reforms and opening-up policies, about ten countries added to this number. Nowadays, apart from Eswatini (which is still having diplomatic relations with Taiwan), all the African countries have formal diplomatic ties with the Middle Kingdom (PRC). Therefore, throughout time, the political condition has remained the same: the recognition of China's full sovereignty on Taiwan (considered as China's Province). This 
condition is direct, simple and easy to be satisfied by African countries which are facing difficulties to satisfy political conditions and complex regulations imposed by the aid system of Western democracies. It is also remarked that if in the 1960s and 1970s China's aid was dependent on an adherence to the communist ideology, it got rid of this for a policy more adapted to the international political context prevailing at the end of the Cold War (Shi). The fourth section presents these changes with more details.

\section{An Idealistic but Pragmatic Policy}

The idealists agree with the realists to consider the Chinese aid for development as a foreign policy instrument, but with much more positive objectives. The individuals hold, generally, a more nuanced view. For example, Moyo, a pessimist of foreign aid in Africa is much more conciliating with that of China (Easterly, 2009). According to her, aid is the problem but not the solution to African development. The solution is a trade-centered approach, which the Chinese aid must conform to (Moyo, 2013). As stated by Mayo, China's growing presence is an opportunity which should be seized by African countries to boost their economic development. The Chinese player is a giver whose aid completes the efforts of traditional Western aid (Brautigam, 2011). On the whole, these authors highlight aspects showing a certain degree of ambivalence in their perceptions of China's aid in Africa. The Chinese player's words and actions, much more, clarify this singularity.

The Chinese player's words have evolved through time and space to get adapted to current political and economic circumstances, but still remaining courteous. For instance, in the 1960s the then-Chinese Prime Minister, Chou Enlai, had a set of eight principles published:

The eight principles for economic development and technical cooperation with other countries: 1. Equality and mutual benefit between donors and receivers should be guaranteed. 2. Non-interference in domestic affairs and respect for national sovereignty. 3. Loans with no interest or loans with preferential interests are granted. 4. The main goal of aid is consolidating receiving countries' self-dependence. 5. Support projects which produce fast results, increased income, and accumulate the capital; 6. Development projects are implemented with quality Chinese equipment. 7. Technical aid and local people's vocational training are guaranteed. 8. Chinese aid volunteers should adopt local people's standards of living (Lengauer, 2011).

These principles were edited and published in the Cold War context which is characterized by bipolarization. China, as a communist country, evolving in the framework of South-South cooperation offered its aid to countries which submitted to its principles, but in addition to this, were also communists. After the Cold War and particularly in the early $21^{\text {st }}$ century major changes occurred in the Chinese foreign policy, mainly in its approach to foreign aid. Firstly, for the first time in its history, China published two official reports in 2011 and 2014. These documents reveal the procedure, means and goals of its aid policy. This evolution testifies the renewed importance of aid in China's African policy as it is shown in the second official report:

China is the largest developing country in the world. While developing, it made efforts to integrate Chinese populations' interests into those of populations in other countries, offering assistance at the top of its capacity to other developing countries in the framework of 
South-South cooperation, support and help other developing countries, particularly the less developed countries $(L D C)$, reduce poverty and improve their living conditions. China has pro-actively promoted international cooperation and development and played a constructive role in this aspect. When it offers foreign aid, China adheres to the principles of imposing no political condition, non-interference in receivers' domestic affairs, fully respecting their right to choose, freely, their own ways and models of development (Information Office of the State Council, 2014).

This speech was delivered to reassure and bring countries closer together. Despite being a superpower, China puts itself on the same level as Africa. The following sentence "China is the largest developing country" plays two roles: the first is to convince countries receiving aid that it (China) knows and understands very well their situation because it had faced similar problems in the past. The second is to show that it remains a friend endeavoring to help them in their development process. Following the same logic, it does not fail in being pragmatic. It offers aid depending on its capacities. While helping others, it accomplishes a duty incumbent on its international great power status of contributing to the common good (fighting poverty by helping countries which are facing difficult economic conditions). It reasserts its adherence to equality and mutual benefit. It is a brotherly, courteous speech but at the same time direct and pragmatic. Here, the use of conciliating dualism of Chinese strategy can be noticed. It proposes a speech different from that of the Western aid, because it praises the ego of Africans who have, for long, been despised and frustrated by the disbursement process and traditional aid conditions.

Also, Chinese leaders have never failed to claim their expertise in foreign aid matters. As Bräutigan (2011) explained, "The Chinese have six decades of experience with aid in Africa. They've spent time analyzing their own past failed aid projects, and they've come up with a different model of engagement, much of which does not actually involve official development aid".

\section{Conclusion}

The analyses of the political conditions and the Chinese player's speech started in the above-mentioned sections testify to the conciliating dualism of the Chinese aid policy in Africa through time and space. This policy is neither realistic nor idealistic. It associates elements of both paradigms by getting its inspiration from ancient principles resulting from the country's strategic culture. This specificity was mentioned by Henri Kissinger (2002) when he says the Chinese "exceptionalism" is deeply rooted in the Chinese culture, proclaiming no institutional hegemony out of China. This policy is also getting closer to contemporary theories and concepts of international politics such as the "smart power" used by the American economist Joseph Nye (2019), meaning, the capacity of combining an attractive power with a coercive one and associating both to an economic power.

\section{Acknowledgements}

This research received no specific grant from any funding agency, commercial or not-for-profit sectors. We thank Dr. Suryappa J. PAWAR, Professor of Motilal Nehru National Institute of Technology, Allahābād (MNNIT) in India, Dr. Wong Mun Wui of The School of Foreign Languages of Nanfang College of Sun Yat-Sen University, the editor, and the anonymous 
reviewers of the Journal of Social Science Studies for helpful comments on earlier versions of this article.

\section{References}

Bergère, M.-C. (1 ${ }^{\mathrm{er}}$ janvier 1987). La République Populaire de Chine de 1949 à nos Jours. Paris: Armand Colin, 283 p.

Bräutigam, D. (August 2011). China in Africa: What Can Western Donors Learn? A report for Norfund,

Bräutigam, D. (2011). The Dragon's Gift: The Real Story of China in Africa, UK: Oxford,

Bräutigam, D. (2011). "Aid 'with Chinese Characteristics: Chinese Foreign Aid and Development Meet the OECD-DAC Aid Regime," Journal of International Development, 1-13. https://doi.org/10.1002/jid.1798

Callan, T. C. (2000). US Foreign Aid in Complex Humanitarian Emergencies: Motivation behind Aid in Western Europe, Cambodia, Ethiopia, and North Korea, New York: State University of New York at Buffalo Press.

Chaponnière, J.-R. (2008). Un Demi-Siècle de Relations Chine-Afrique: Évolution des Analyses. In Afrique Contemporaine 4, 35-48. https://doi.org/10.3917/afco.228.0035

China's Foreign Aid. (10 July 2014). China's Foreign Aid, Information Office of the State Council, The People's Republic of China, Beijing.

Dollar, D., \& Pritchett L. (1998). Assessing Aid. What Works, What Doesn't and Why. The World Bank, Oxford University Press, New York.

Easterly, W. (June 2009). Review of Dambisa Moyo's book “Dead Aid”. London Review of Books, but then LRB rejected it for publication.

Ethier, D. (2010). Introduction aux Relations Internationales. Montréal, Presse de l’Université de Montréal, 4eme édition, 135-198. https://doi.10.4000/books.pum.6398

Gabas J. J. (ed.), Chaponnière J. R. (2012). Le Temps de la Chine en Afrique: enjeux et réalités au sud du Sahara, Paris: Karthala (Hommes et sociétés).

Herzberg, H. (26 January 2009). Smart Power. The New Yorker.

Huang, M., \& Ren, P. (2012). China's Foreign Aid and Its Role in the International Architecture. In G. Carbonnier (Ed.), International Development Policy: Aid, Emerging Economies and Global Policies, Vol. 3, 75-88). London: Palgrave Macmillan. https://doi.org/10.4000/poldev.1004

Hunt, M. (1996). The Genesis of Chinese Communist Foreign Policy. New York: Columbia University Press.

Iain, J. A. (1995). Cultural Realism: Strategic Culture and Grand Strategy in Chinese History. Princeton NJ: Princeton University Press.

Fairbank, J. K. (1968). The Chinese World Order: Traditional China Foreign Relations. Cambridge MA: Harvard University Press.

Huang, K., \& Huang, R. (1987). I Ching. Workman Publishing Company, N.Y.; 3rd Printing Edition.

Information Office of the State Council, The People's Republic of China. July 2014. "China's 
Foreign Aid, Xinhua, Beijing.

Kissinger, H. (2002). On China. New York: Penguin Book.

Lacroix. (4 Septembre 2018). "La Chine Vante son Aide sans 'Conditions' à l'Afrique". [Online]

Lafargue, F. (Juillet-Août 2005). "La Chine, une Puissance Africaine", In Perspectives Chinoises, No. 90, 1-10.

Lao-Tseu. (1984). Tao Te King. Paris: Albin Michel.

Lengauer, S. (September-December 2011). China's Foreign Aid Policy: Motive and Method. Culture Mandala: The Bulletin of the Centre for East-West Cultural and Economic Studies, 9 (2), 3, 35-81.

Lai, D. (May 2004). Learning from the Stones: A Go Approach to Mastering China's Strategic Concept, Shi, United States Army War College.

Marshall Plan, formally European Recovery Program, (April 1948-December 1951).

Li, X. (2006). China's Foreign Aid and Aid to Africa: Overview, College of Humanities and Development, China Agricultural University, China.

Lin, Chong-Pin (April 26, 2002). Beijing's Agile Tactics on Taiwan: paper presented at the conference "The Political and Economic Reforms of Mainland China in a Changing Global Society", National Taiwan University, Taipei.

Lin, C-P (Winter 2008). More Carrot Than Stick: Beijing's Emerging Taiwan Policy. China Security, 4(1), 3-29.

Moyo, D. (February 2013). Interview CNN.

Moyo, D. (2009). Dead Aid: Why Aid Is Not Working and How There is another Way for Africa. New York: Farrar, Straus and Giroux.

Nye, J. (2004). Soft Power: The Means to Success in World Politics. New York: Public Affairs.

Sawyer, R.D. (1993). The Seven Military Classics of Ancient China. Oxford Laurent, François ed. Sun Tse (Sun Zi: L'Art de la Guerre. Paris : Agora Presses).

Shih C.-y. (1993). China's Just World: The Morality of Chinese Foreign Policy. Boulder \& London: Lynne Rienner Publishers.

Thérien, J. P. (Printemps 2001). “Un Demi-Siècle d'Aide au Développement," Les Frontières du Social: Nationales, Transnationales, Mondiales? Issue 45, 89-103.

Thaler, F. (2012). China's Foreign Aid to Africa: New Donors May Help Results. In Washington Post.

Tzu, S. (1971/2019). The Art of War, Oxford University Press, Chap.3-6. (Samuel B. Griffith Translation).

Wang, X., \& Ozanne, A., \& Xin, H. (2014). The West's Aid Dilemma and the Chinese Solution," Journal of Chinese Economic and Business Studies, 12(1), 47-61. https://doi.org/10.1080/14765284.2013.875287

Weston, J., Campbell, C., \& Koleski K. (September 1, 2011). China Foreign Assistance in Review: Implications for the United States. In U.S.-China Economic and Security Review 
Commission: Staff Research Backgrounder, 1-14.

Xinhua (July 2014). China's Foreign Aid, Office of the State Council, The People's Republic of China.

Xinhuanet. (2018). La Chine adhère au développement pacifique et ne recherche pas l'hégémonie (MAE chinois), 2018-09-29, in French Xinhua.

Xinhuanet (2020). Xi Jinping: la Chine ne cherche jamais l'hégémonie ni l'expansion.

Yin \& Yang: Signification (2016). Le Journal des Bonnes Nouvelles.

Zamora, S. (1997). Economic Relations and Development" in The United Nations and International Law, ed. Christopher C. Joyner (Cambridge: Cambridge University Press).

Zhu, L. (September 2010). China's Foreign Policy Debates." European Union Institute for Security Studies (EUISS), Paris, Challot Papers, 16.

\section{Copyright Disclaimer}

Copyright for this article is retained by the author(s), with first publication rights granted to the journal.

This is an open-access article distributed under the terms and conditions of the Creative Commons Attribution license (http://creativecommons.org/licenses/by/4.0/). 